\title{
Activation of pepsin (EC 3.4.4.1) by heavy-metal ions including a contribution to the mode of action of copper sulphate in pig nutrition
}

\author{
By M. KIRCHGESSNER, M. G. BEYER AND H. STEINHART \\ Institut für Tierernährung der Technischen Universität München, \\ D-8050 Freising-Weihenstephan, West Germany
}

(Received I9 May 1975 - Accepted 2 fanuary 1976)

\begin{abstract}
1. Kinetic experiments were done with pepsin $(E C$ 3.4.4.1) using haemoglobin as a substrate in the presence of different metal cations.

2. The activation of peptic hydrolysis with higher concentrations of cupric ions added to the reaction mixture was determined from turnover-rate curves in experiments with constant substrate concentration. With a $\mathrm{Cu}^{2+}$ concentration greater than $1.67 \times 10^{-4} \mathrm{M}$ activation was obtained

3. Nickel jons at a concentration of $8.33 \times 10^{-4} \mathrm{M}$ and at higher concentrations also increased pepsin activity. Additions of ferrous ions and zinc ions had no effect.

4. Experiments were done using variable substrate concentrations in the presence of different $\mathrm{Cu}^{2+}$ concentrations. The concentrations of haemoglobin ([S]) at half maximum velocity were determined. The double-reciprocal plots of [S] $v$. reaction velocity ( $v$ ) (i.e. $I /[S] v . I / v)$ had no common intersection point. Therefore the kinetics did not correspond to any of the known kinetics. The activation brought about by $\mathrm{Cu}^{2+}$ cannot easily be explained by the study of the kinetics. Certain simple explanations of the phenomenon can be eliminated.
\end{abstract}

Copper addition to the diet improves the weight gain of pigs and the food consumption/kg weight gain (for reviews, see Braude, 1967; Wallace, 1967; Meyer \& Kröger, 1973). Among other factors, the increased food intake, the bactericidal activity of $\mathrm{Cu}$, and the improved absorption of amino acids are discussed as causes. An improvement in the digestibility of proteins after doses of $\mathrm{Cu}$ was found with young pigs in the weight range up to $25 \mathrm{~kg}$ (Kirchgessner \& Giessler, 196I; Castell \& Bowland, I968a,b). Kinetic experiments with pepsin $(E C 3.4 .4$. I $)$ in the presence of various concentrations of cupric sulphate should determine to what extent the improved digestibility of protein was caused by a positive influence on the digestive enzymes. At the same time, the influence of nickel sulphate, ferrous sulphate and zinc sulphate on the activity of pepsin was studied.

\section{EXPERIMENTAL}

Commercially available pepsin from pig mucosa was purchased from E. Merck AG, Darmstadt, West Germany. The initial activity was $15 \mathrm{mAnson}$ units $(\mathrm{mA}) / \mathrm{mg}$, where I Anson unit is equivalent to the amount of enzyme which liberates under test conditions I mmol Folin-positive amino acids (calculated as tyrosine)/min. Haemoglobin was used as a substrate. The test conditions were those described by Hennrich \& Brümmer (1973). The activities of pepsin in our experiments were determined using the method described by Rick \& Fritsch (1970), with haemoglobin as a substrate. The activities of pepsin in the presence of $\mathrm{CuSO}_{4}, \mathrm{NiSO}_{4}, \mathrm{FeSO}_{4}$, and $\mathrm{ZnSO}_{4}$ were determined with constant substrate concentrations and variable reaction times, and in addition, kinetic studies were made with variable substrate concentrations and constant reaction times in the presence of $\mathrm{CuSO}_{4}$. 


\section{Reactions with variable substrate concentrations}

Pepsin ( $30 \mathrm{mg}$ ) was dissolved in $110.0 \mathrm{I} \mathrm{M-HCl}$ to give a stock solution of activity $0.45 \mathrm{~mA} / \mathrm{ml}$. One $\mathrm{ml}$ stock solution of pepsin was mixed with $0,0.1,0.2$ or $0.5 \mathrm{ml}$ $0.0 \mathrm{I} \mathrm{M}-\mathrm{CuSO}_{4}$ and diluted with $0.06 \mathrm{M}-\mathrm{HCl}(0-4.7 \mathrm{ml}$, depending on the volume of haemoglobin solution to be added). This mixture was shaken at $25^{\circ}$ for 25 min for the $\mathrm{Cu}^{2+}$ to react with the pepsin. A solution of haemoglobin $(20 \mathrm{~g} / 1)$ in $0.06 \mathrm{M}-\mathrm{HCl}$ was added as substrate in volumes varying from 0.2 to $4.5 \mathrm{ml}$ (4-90 mg haemoglobin). The amounts of haemoglobin solution and $\mathrm{HCl}$ solution were adjusted so that the final volume in all instances was $6 \mathrm{ml}$, the pepsin activity $0.075 \mathrm{~mA} / \mathrm{ml}$, and the $\mathrm{Cu}^{2+}$ concentrations $\mathrm{r} .67 \times 10^{-4} \mathrm{M}, 3.33 \times 10^{-4} \mathrm{M}$ or $8.33 \times 10^{-4} \mathrm{M}$.

The enzymic reaction was started by the addition of haemoglobin solution. The $\mathrm{pH}$ of the reaction mixtures was $\mathrm{I}^{\circ} \mathrm{9}$. The experiments were done in a shaking incubator at $25^{\circ}$, with a reaction time of $10 \mathrm{~min}$. The reaction was stopped by the addition of $10 \mathrm{ml}$ trichloroacetic acid solution (5० g/l) (TCA).

A blank was prepared for every haemoglobin and $\mathrm{CuSO}_{4}$ concentration. For this, Io $\mathrm{ml} \mathrm{TCA}$ were immediately added to the reaction mixtures so that no enzymic transformation resulted.

\section{Reaction mixtures with constant substrate concentrations}

The stock solution of pepsin contained $75 \mathrm{mg}$ pepsin/ $10.0 \mathrm{I} \mathrm{M}-\mathrm{HCl}$, and had an activity of $\mathrm{I} \cdot \mathrm{I}_{3} \mathrm{~mA} / \mathrm{ml}$. $\mathrm{CuSO}_{4}, \mathrm{NiSO}_{4}, \mathrm{FeSO}_{4}$ and $\mathrm{ZnSO}_{4}$ all at concentrations of $0.02 \mathrm{M}$ were added to $5 \mathrm{ml}$ of the stock solution of pepsin, and each solution was then diluted to $10 \mathrm{ml}$ with $\mathrm{O} \cdot \mathrm{OI} \mathrm{M}-\mathrm{HCl}$ so that in the reaction mixtures the concentrations ( $\mathrm{M}$ ) were: $\mathrm{Cu}^{2+}, 8 \cdot 33 \times 10^{-4}, 5 \cdot 00 \times 10^{-4}, \mathrm{I} \cdot 67 \times 10^{-4} ; \mathrm{Ni}^{2+}, \mathrm{Fe}^{2+}, \mathrm{Zn}^{2+}, \mathrm{I} \cdot 670 \times 10^{-3}, 8 \cdot 33 \times 10^{-4}$. These solutions were shaken at $25^{\circ}$ in the shaking incubator. Then each solution was mixed with $50 \mathrm{ml}$ haemoglobin solution $(20 \mathrm{~g} / 10.06 \mathrm{M}-\mathrm{HCl})$. After mixing these reagents, $5 \mathrm{ml}$ were removed immediately from each mixture and added to ro $\mathrm{ml}$ TCA. The remainder of the reaction mixture was maintained, with shaking, at $25^{\circ}$. Beginning at $0 \mathrm{~min}$, when the solutions were mixed, a total of eight $5 \mathrm{ml}$ samples of the reaction mixture were withdrawn at 2 min intervals and the reaction was stopped with TCA. At the beginning of the reaction the $\mathrm{pH}$ was $\mathrm{I} \cdot 9$.

\section{Analysis of the reaction mixtures}

The reaction mixtures treated with TCA were centrifuged at $4000 \mathrm{~g}$ for $20 \mathrm{~min}$. From each supernatant fraction $5 \mathrm{ml}$ were taken, mixed with $10 \mathrm{ml} 0.55 \mathrm{M}$-sodium hydroxide, and then $3 \mathrm{ml}$ diluted phenol reagent (Io $\mathrm{g}_{2} \mathrm{WO}_{4} .2 \mathrm{H}_{2} \mathrm{O}, 2.5 \mathrm{~g}$ $\mathrm{Na}_{2} \mathrm{MoO}_{4} \cdot 2 \mathrm{H}_{2} \mathrm{O}$, ${ }_{5} \mathrm{~g} \mathrm{Li}_{2} \mathrm{SO}_{4}$, $10 \mathrm{ml}$ conc. $\mathrm{HCl}, 5 \mathrm{ml}$ conc. $\mathrm{H}_{3} \mathrm{PO}_{4}$, and distilled water to $100 \mathrm{ml}$ ) was added with shaking. A blue-coloured complex developed after so min at $25^{\circ}$, and the extinction at $578 \mathrm{~nm}$ was determined spectrophotometrically, using Io $\mathrm{mm}$ glass cuvettes, with the corresponding blank solutions for comparison. To obtain the standard curve, the same procedure was applied to standard solutions containing $0.04,0.08,0.12,0.16$ and $0.20 \mu \mathrm{mol}$ tyrosine $/ 10.2 \mathrm{M}-\mathrm{HCl}$. The reagent blank was $0.2 \mathrm{M}-\mathrm{HCl}$. 


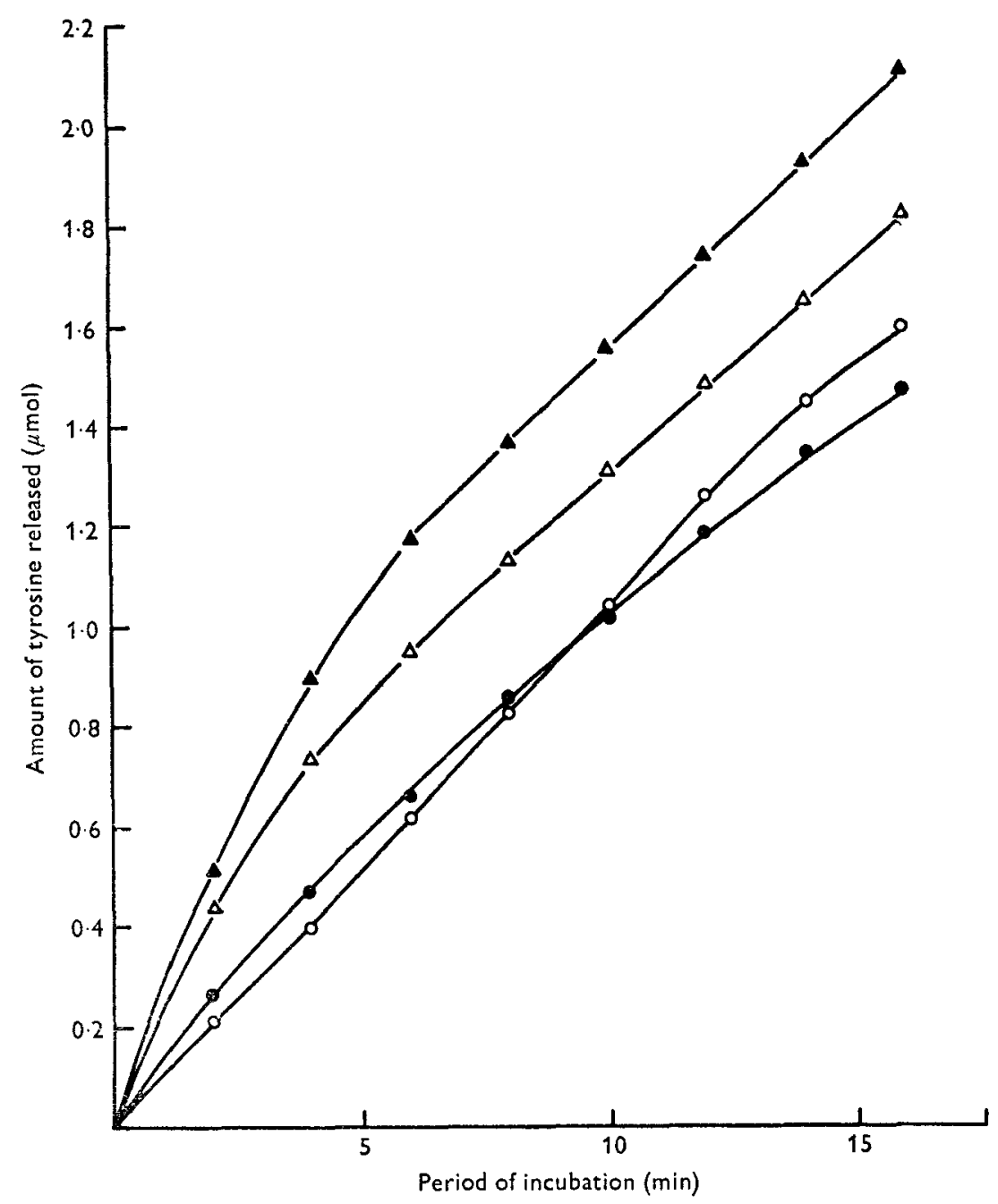

Fig. 1. Turnover-rate curves for the pepsin (EC 3.4.4. I)-catalysed hydrolysis of haemoglobin (expressed as $\mu \mathrm{mol}$ tyrosine released) in the presence of different concentrations of cupric ions: $O-O$, control $(O \mathrm{M}) ;-1.67 \times 10^{-4} \mathrm{M} ; \triangle-\triangle, 5^{\circ} 00 \times 10^{-4} \mathrm{M} ; \Delta-\Delta, 8.33 \times 10^{-4} \mathrm{M}$. For details of experimental procedures, see p. I6.

\section{RESULTS}

Turnover-rate curves for peptic hydrolysis in the presence of trace elements

The influence of trace elements on pepsin activity was determined using turnoverrate curves. These were obtained from studies of pepsin activity using haemoglobin as the substrate, with the addition of some trace elements at different concentrations.

Fig. I shows the turnover-rate curves at different concentrations of $\mathrm{Cu}^{2+}$. In the control experiment (without $\mathrm{Cu}^{2+}$ ) the reaction velocity slowly decreased after $14 \mathrm{~min}$. With $\mathrm{I} \cdot 67 \times \mathrm{IO}^{-4} \mathrm{M}-\mathrm{Cu}^{2+}$ the reaction velocity was increased slightly at the beginning of incubation, when compared with the control, but after about $5 \mathrm{~min}$ it decreased 


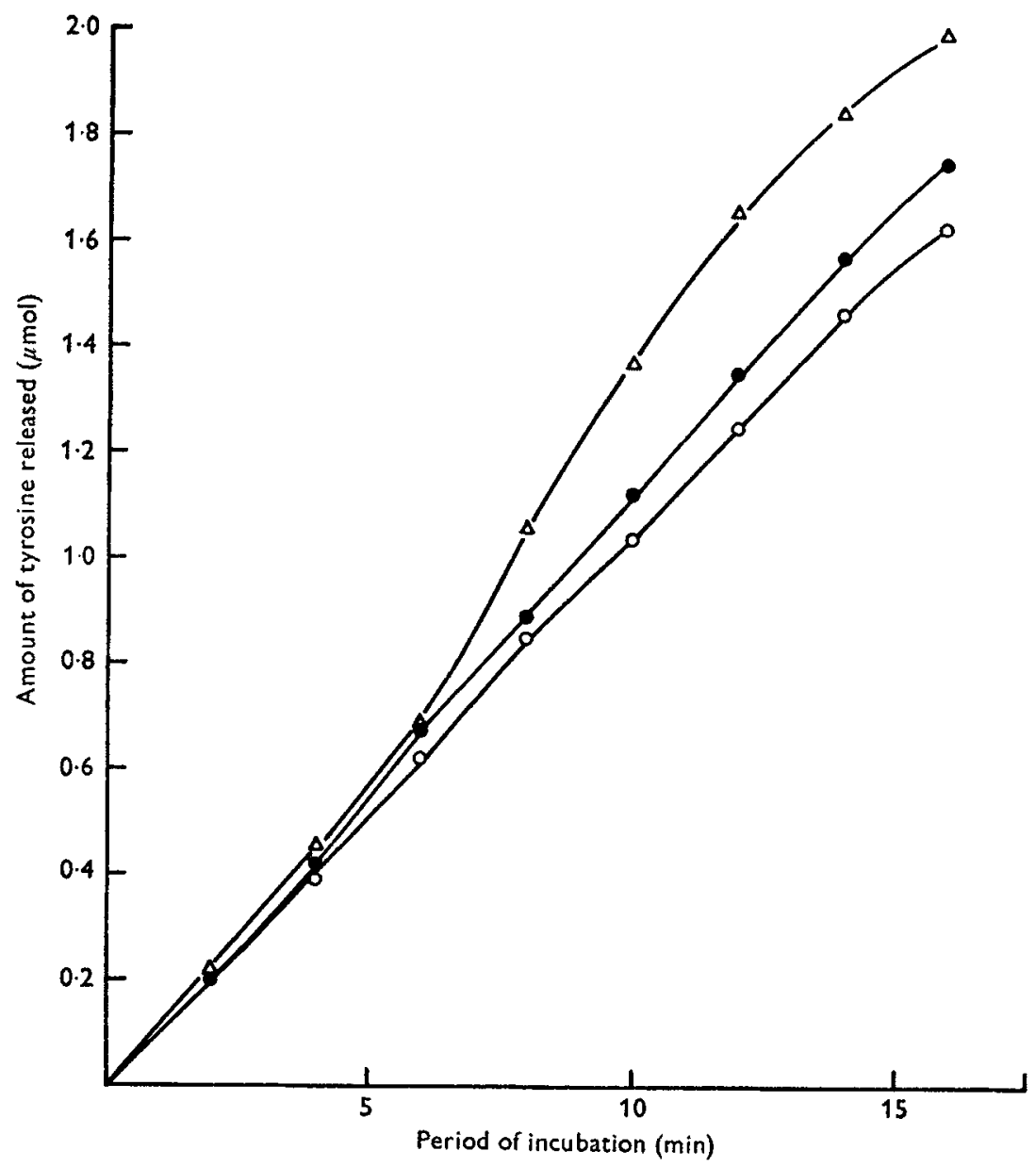

Fig. 2. Turnover-rate curves for the pepsin $(E C$ 3.4.4.1)-catalysed hydrolysis of haemoglobin (expressed as $\mu \mathrm{mol}$ tyrosine released) in the presence of different concentrations of nickel ions: $\mathrm{O}-\mathrm{O}$, control $(\mathrm{OM}) ;-, 8.33 \times 10^{-4} \mathrm{M} ; \Delta-\Delta, \mathrm{I} .67 \times 10^{-8} \mathrm{M}$. For details of experimental procedures, see p. 16.

more rapidly than the control so that less tyrosine was liberated from haemoglobin with increasing reaction time. Thus peptic hydrolysis was activated only at the beginning of the reaction; subsequently a slight inhibition occurred. When the concentration of the $\mathrm{Cu}^{2+}$ was increased to $5 \times 10^{-4}$ or $8.33 \times 10^{-4} \mathrm{M}$, the initial velocities increased more rapidly in response to the higher $\mathrm{Cu}^{2+}$ concentration. Consequently, the two higher $\mathrm{Cu}^{2+}$ concentrations have an essentially higher reaction velocity, particularly at the beginning of the reaction, as compared with the control experiments, but as the reaction progressed, the differences become smaller. Throughout the reaction period, however, an activation of peptic hydrolysis by $5 \times 10^{-4}$ and $8.33 \times 10^{-4} \mathrm{M}-\mathrm{Cu}^{2+}$ was evident.

Fig. 2 shows the turnover-rate curves for reaction mixtures in the presence of $\mathrm{Ni}^{2+}$. The curve obtained with $8.33 \times 10^{-4} \mathrm{M}-\mathrm{Ni}^{2}+$ did not differ from the control curve in 


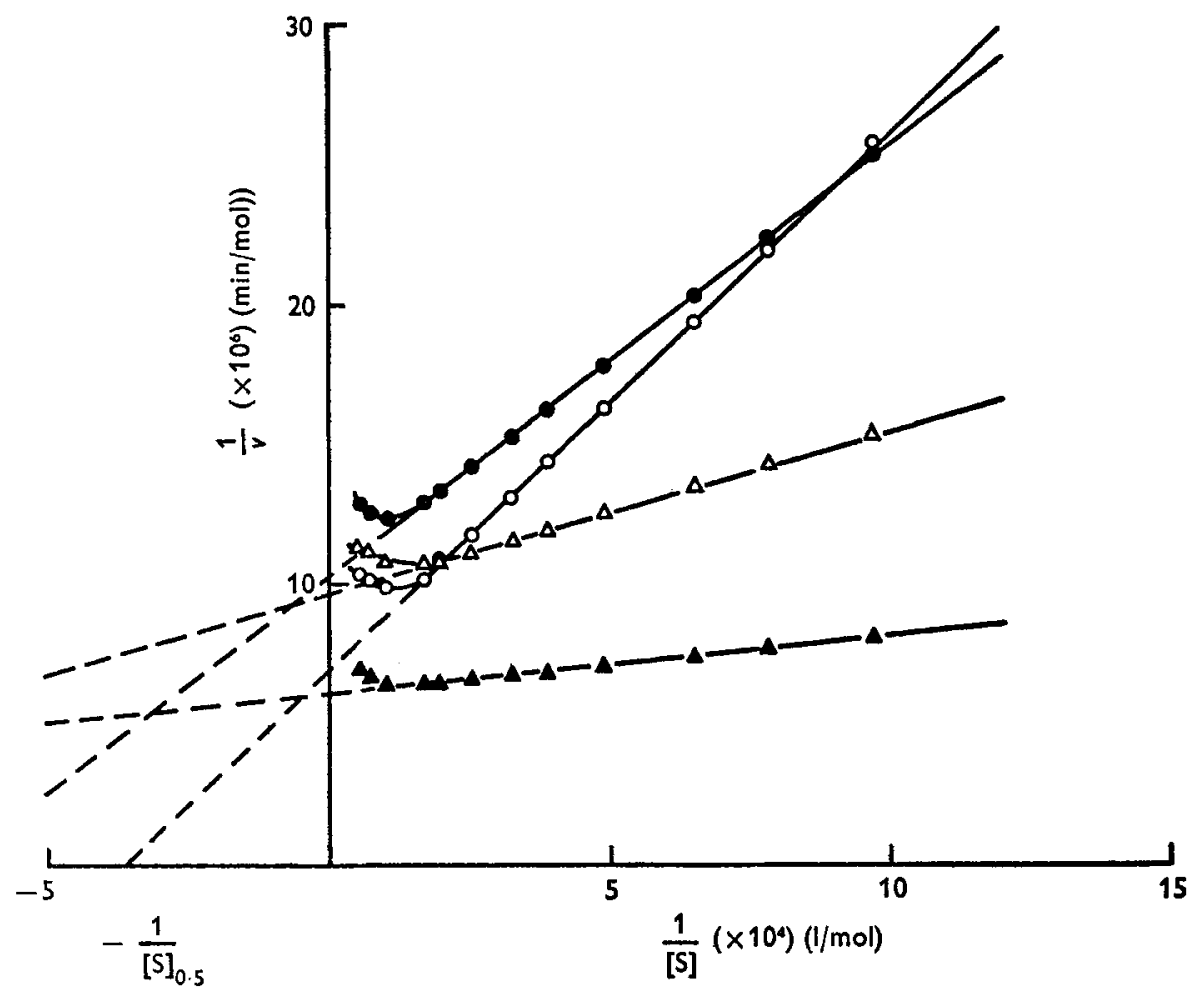

Fig. 3. Double-reciprocal plot for haemoglobin concentration ([S]) (M) v. reaction velocity (v) ( $\mu \mathrm{mol}$ tyrosine released $/ \mathrm{min}$ ) (i.e. I/([S]) $v$. $\mathrm{r} / v$ ) for the pepsin $(E C 3 \cdot 4.4 . \mathrm{I})$-catalysed hydrolysis of haemoglobin in the presence of different concentrations of cupric ions: $\mathrm{O}-\mathrm{O}$, control $(\mathrm{OM}) ;-\mathrm{O}, \mathrm{I} .67 \times 10^{-4} \mathrm{M} ; \Delta-\Delta, 3.33 \times 10^{-4} \mathrm{M} ; \Delta-\Delta, 8.33 \times 10^{-4} \mathrm{M}$.

the first few minutes of the reaction period. However, as the reaction progressed the slope became steeper than that of the control curve; the reaction velocity increased. The difference in the reaction velocity was also slight with $\mathrm{I} .67 \times \mathrm{IO}^{-3} \mathrm{M}-\mathrm{Ni}^{2+}$ at the beginning of the reaction, compared with the control. However, the reaction velocity increased very rapidly after $6 \mathrm{~min}$. Thus the velocity of peptic hydrolysis also increased with higher $\mathrm{Ni}^{2+}$ concentrations.

At the concentrations used, $\mathrm{Fe}^{2+}$ and $\mathrm{Zn}^{2+}$ had no effect on the rate of peptic hydrolysis.

\section{Peptic hydrolysis at different substrate concentrations in presence of $\mathrm{Cu}^{2+}$ ions}

Fig. 3 shows the plot of the reciprocal concentrations of haemoglobin $v$. the reciprocal reaction velocities for the pepsin-catalysed hydrolysis of haemoglobin in the presence of various concentrations of $\mathrm{Cu}^{2+}$. The amounts of tyrosine liberated from haemoglobin/min that were not precipitable by TCA were taken as a measure of the reaction velocity.

Fig. 3 cannot be considered as a normal Lineweaver-Burk plot. As the results shown in Fig. I have indicated, it is difficult to study reactions in the presence of $\mathrm{Cu}^{2+}$ during 
a reaction period for which the velocity remains constant and the concentrations of haemoglobin cannot be equated with the concentration of substrate, since pepsin may attack different peptide bonds in haemoglobin at different rates. Despite these limitations, the substrate concentrations ([S]) at half maximum velocity (i.e. [S] $]_{0.5}$ (Koshland, Nemethy \& Filmer, 1966)) were determined as relative kinetic measurements. The $[\mathrm{S}]_{0.5}$ values $(\mathrm{M})$ at $\mathrm{Cu}^{2+}$ concentrations $(\mathrm{M})$ of $\mathrm{O}, \mathrm{I} \cdot 67 \times 10^{-4}, 3.33 \times 10^{-4}$ and $8.33 \times 10^{-4}$ were $2.8 \times 10^{-5}, 1.6 \times 10^{-5}, 6.3 \times 10^{-6}$ and $3.4 \times 10^{-6}$ respectively.

The results in Fig. 3 indicated that the kinetics of the reported reactions cannot be compared with any known kinetics (e.g. competitive or non-competitive activation), because the plots for the different $\mathrm{Cu}^{2+}$ concentrations do not intersect that for the control (without $\mathrm{Cu}^{2+}$ ) at either the ordinate or the abscissa. As there is no common intersection of the different plots in any of the quadrants of the coordinate system, there cannot be a mixed activation. Therefore, it cannot be excluded that other effects, so far unknown, are involved in the activation of pepsin by high $\mathrm{Cu}^{2+}$ concentrations, so that pepsin obeys different kinetics in the presence of relatively large amounts of $\mathrm{Cu}^{2+}$, as it does also in the absence of $\mathrm{Cu}^{2+}$ (cf. in Fig. I the partly nonlinearity of the turnover-rate curves). A strong substrate inhibition is indicated in all plots for the range of high enzyme-substrate concentrations.

\section{DISCUSSION}

The results of the kinetic experiments indicated that $\mathrm{Cu}^{2+}$ particularly, but also $\mathrm{Ni}^{2+}$, increases pepsin activity, while $\mathrm{Fe}^{2+}$ and $\mathrm{Zn}^{2+}$ do not. The influence of $\mathrm{Cu}^{2+}$ and $\mathrm{Ni}^{2+}$ depends on their concentrations. Thus the effect of different amounts of $\mathrm{Cu}$ additives in pig fattening, which is indicated by, among other factors, improved protein digestibility (Kirchgessner \& Giessler, 1961; Braude, I965; Castell \& Bowland, $1968 a, b$ ) could be attributed to the positive influence of $\mathrm{Cu}^{2+}$ on the activity of pepsin. However, there are some workers who have not found a positive influence of $\mathrm{Cu}^{2+}$ additives on the digestibility of organic matter, mainly when older fattening pigs are studied (Beames \& Lloyd, 1964; Combs, Ammerman, Shirley \& Wallace, 1966; Farries \& Angelowa, 1967; Galik, 1969; Young, Brown, Ashton \& Smith, 1970). Kirchgessner, Roth \& Roth-Maier (1974) and Kirchgessner, Roth-Maier \& Roth (1975) even found a reduction of $2-4 \%$ in protein digestibility for fattening pigs in the range $45-70 \mathrm{~kg}$, at certain concentrations of different trace elements. Schröder (I966) stated that peptic hydrolysis is influenced negatively in the presence of some cations, e.g. $\mathrm{Cu}^{2+}$. In studies of in vitro digestion of pepsin with soya-bean protein as substrate, Beyer, Kirchgessner \& Steinhart $(1975 a, b)$ found a greater inhibitory effect in the presence of $\mathrm{Cu}^{2+}, \mathrm{Ni}^{2+}$ and $\mathrm{Fe}^{2+}$ than with $\mathrm{Zn}^{2+}$.

These findings, which appear contradictory at first sight, can be explained as an effect of the cations which depends on cation concentration. The positive influence of $\mathrm{Cu}^{2+}$ and $\mathrm{Ni}^{2+}$ on pepsin activity in the kinetic experiments increased with increasing concentrations of the cations. With $\mathrm{Cu}^{2+}$ and $\mathrm{Ni}^{2+}$ concentrations in the reaction mixture of less than about $\mathrm{I} \cdot 7 \times 1 \mathrm{10}^{-4} \mathrm{M}$ even an inhibition of pepsin could be obtained (Beyer, Steinhart \& Kirchgessner, 1976). The cause of the effects of cations 
on pepsin must be considered in connexion with the formation of a complex between pepsin and the cations. The positive influence of the cations could be the result of the stabilization of the conformation of the pepsin. Steinhart, Beyer \& Kirchgessner (1975) found that pepsin can still form metal ion complexes in the optimal $\mathrm{pH}$ range of pepsin activity $(\mathrm{pH} 2)$ because of its low isoelectric point $(<\mathrm{I})$. As pepsin succumbs to autocatalytic decomposition rather quickly (Determann, Jaworek, Kotitschke \& Walch, I969) the autocatalysis could be reduced by complex formation with cations so that, over all, a greater pepsin activity is reached. An inhibition of pepsin is found with cation concentrations in the reaction mixture of less than about $8.3 \times 10^{-5} \mathrm{M}$ (Beyer et al. 1976). This could explain why the stabilizing effect is not as marked, and that the inhibitory effect prevails.

The activation of pepsin by trace elements could be indicated best by the use of turnover-rate curves. The turnover-rate curves obtained, however, do not comply with the ideal steady-state conditions, especially those for the reaction mixtures containing trace elements, since only sections of these curves are linear. Some of the difficulties of kinetic studies with proteolytic enzymes are discussed critically by Dixon \& Webb (I966); the divergencies are smaller with synthetic substrates. It may be supposed therefore that the kinetics are much more complex with natural substrates than with synthetic ones, particularly because the conformation of protein has a decisive influence on the catalytic cleavage. This is why the kinetics of pepsin have not been widely studied. In the instance of nutritionally relevant experiments, however, natural substrates would be used in preference to artificial substrates, even at the risk that not all conditions required for kinetic studies are strictly met. Therefore, the results of the present studies are only related to some of the bonds hydrolysed by pepsin and, consequently, must be seen strictly as relative values. Even though we did not determine Michaelis constants $\left(K_{m}\right)$ it may be interesting to give some $K_{m}$ values obtained for reactions of pepsin with some synthetic substrates. For the peptic cleavage of carbobenzoxy-L-glutamyl-L-tyrosine, Casey \& Laidler (1950) determined $K_{m}$ as $\mathrm{I} \cdot 9 \times \mathrm{IO}^{-3} \mathrm{M}$ at $\mathrm{pH} 4 \cdot 0$. Baker (1954) found a $K_{m}$ of $2 \cdot 4 \times 10^{-3} \mathrm{M}$ with acetyl-Lphenylalanyl-L-tyrosine, and of $6.3 \times 10^{-3} \mathrm{M}$ with acetyl-L-tyrosyl-L-tyrosine, both at $\mathrm{pH} 2 \cdot 0$. Jackson, Schlamowitz \& Shaw (1965) reported a value of $2.5 \times 10^{-5} \mathrm{M}$ for $N$-acetylphenylalanyl-diiodotyrosine. These values with defined substrates suggest that the kinetics of pepsin may be complex. If it is accepted that our constants $[\mathrm{S}]_{0.5}$ are relevant to statements concerning the influence of trace elements on the kinetics of pepsin, one may conclude, in accordance with Fig. 3, that the kinetics of these reactions may not be described by known theories. The activation brought about by $\mathrm{Cu}^{2+}$ cannot easily be explained by a study of the kinetics.

The different effects of trace elements on the activity of pepsin could perhaps be explained in terms of the stability constants for the complexes of the various ions with pepsin. Unfortunately the stability constants of these complexes are unknown, but from work with other organic ligands (Irving \& Williams, r953) one would predict that pepsin would form the strongest complexes with $\mathrm{Cu}^{2+}$, followed by $\mathrm{Ni}^{2+}$; the complexes would be weaker with $\mathrm{Zn}^{2+}$ and $\mathrm{Fe}^{2+}$. If so, addition of $\mathrm{Cu}^{2+}$ and $\mathrm{Ni}^{2+}$ above a certain level might have a stabilizing effect on the conformation of pepsin and 
thereby reduce its partial autolysis, whereas the stability of the $\mathrm{Fe}^{2+}-$ pepsin and $\mathrm{Zn}^{2+}$ pepsin complexes would not be sufficient to have this effect, even at higher cation concentrations.

\section{REFERENCES}

Baker, L. E. (1954). F. biol. Chem. 211, 701.

Beames, R. M. \& Lloyd, L. E. (1964). F. Anim. Sci. 23, 1206.

Beyer, M. G., Kirchgessner, M. \& Steinhart, H. (1975a). Z. Tierphysiol. Tierernähr. Futtermittelk. 35. 329.

Beyer, M. G., Kirchgessner, M. \& Steinhart, H. (1975b). Landw. Forsch. 28, 278.

Beyer, M. G., Steinhart, H. \& Kirchgessner, M. (1976). Landw. Forsch. 29, 53.

Braude, R. (1965). Cuprum pro Vita. Trans. Symp. Copper Dev. Ass., Lond. p. 55.

Braude, R. (I 967). Wld Rev. Anim. Prod. 3, 69.

Casey, E. J. \& Laidler, K. J. (1950). F. Am. chem. Soc. 72, 2159.

Castell, A. G. \& Bowland, J. P. (rg68a). Can. F. Anim. Sci. 48, 403.

Castell, A. G. \& Bowland, J. P. (1968b). Can. F. Anim. Sci. 48, 415.

Combs, G. E., Ammerman, C. B., Shirley, R. L. \& Wallace, H. D. (1966). F. Anim. Sci. 25, 6r 3.

Determann, H., Jaworek, D., Kotitschke, R. \& Walch, A. (1969). Hoppe-Seyler's Z. physiol. Chem. 350, 379 .

Dixon, M. \& Webb, E. C. (I966). Enzymes, 2nd ed., p. 6r. London: Longmans, Green \& Co. Ltd.

Farries, E. \& Angelowa, L. (1967). Landw. Forsch. 20, 137.

Galik, R. (1 969). Nutr. Abstr. Rev. 40, 108 r.

Hennrich, N. \& Brümmer, W. (1973). Pharm. Ind., Berl. 35, 269.

Irving, H. \& Williams, R. J. P. (I953). F. chem. Soc. III, 3192.

Jackson, W. T., Schlamowitz, M. \& Shaw, A. (1965). Biochemistry, Easton 4, 1537.

Kirchgessner, M. \& Giessler, H. (1961). Z. Tierphysiol. Tierernähr. Futtermittelk. 16, 297.

Kirchgessner, M., Roth, F. X. \& Roth-Maier, D. A. (1974). Landw. Forsch. 27, 182.

Kirchgessner, M., Roth-Maier, D. A. \& Roth, F. X. (1975). Züchtungskunde 47, 96.

Koshland, D. E., Nemethy, G. \& Filmer, D. (Ig66). Biochemistry, Easton 5, 365.

Meyer, H. \& Kröger, H. (1973). Übers. Tierernähr. r, 9.

Rick, W. \& Fritsch, W.-P. (1970). In Methoden der Enzymatischen Analyse, and ed., p. 362 [H. U. Bergmeyer, editor]. Weinheim: Verlag Chemie.

Schröder, J. (1966). Nahrung 37, 54I.

Steinhart, H., Beyer, M. G. \& Kirchgessner, M. (1975). Z. Lebensmittelunters. u.-Forsch. 159, 73.

Wallace, H. D. (1967). High Level Copper in Swine Feeding. New York: International Copper Research Association Inc.

Young, L. G., Brown, R. G., Ashton, G. C. \& Smith, G. C. (1970). Can. F. Anim. Sci. 50, 717. 